\title{
Skeletal Maturation in Different Vertical Facial Growth Pattern
}

\section{Procjena skeletne zrelosti kod različitih obrazaca vertikalnoga rasta lica}

\author{
${ }^{1}$ Polyclinic Prlić, Osijek \\ Poliklinika Prlic, Osijek \\ 2 Department of Orthodontics, University Clinical Hospital Centre, Zagreb \\ Zavod za ortodonciju Kliničkoga bolničkog centra Zagreb \\ ${ }^{3}$ PhD student, University of Zagreb School of Dental Medicine, Gundulićeva 5, Zagreb \\ Doktorand Stomatološkog fakulteta Sveučilišta u Zagrebu \\ ${ }^{4}$ Department of Orthodontics, University of Zagreb School of Dental Medicine, Gunduliceva 5, Zagreb \\ Zavod za ortodonciju Stomatološkog fakulteta Sveučilišta u Zagrebu
}

\section{Abstract}

Objective: To assess whether there are differences in skeletal maturation among subjects with horizontal, vertical, and neutral facial growth patterns. Material and methods: The study was performed on 48 latero-lateral craniographs of patients with horizontal, 48 with vertical and 50 with neutral growth patterns aged 12 to 18 years. Eight variables from the Zagreb 82 MOD, Bracchetti and Accord analysis, were selected for measuring angular and linear parameters on latero-lateral craniographs. The assessment of skeletal maturation was done by using the CVMS method. Results: Statistical analysis showed significant differences in skeletal maturity $(\mathrm{p}<0.001)$ between subjects with horizontal and vertical growth pattern and between the subjects with neutral and vertical growth pattern $(p<0.05)$, while no significant difference was found between patients with horizontal and neutral growth pattern. In the younger group ( $12-15$ years) there was a statistically significant difference ( $p$ $<0.05)$ among subjects with horizontal and vertical growth patterns. In the older group (16-18 yrs) there was a statistically significant difference $(p>0.05)$ in skeletal maturity among subjects with vertical growth patterns compared with horizontal and neutral. In terms of stages of skeletal maturity, patients with a horizontal and neutral growth pattern in the younger group were on average in the fourth stage, and those with a vertical growth pattern in the third stage. In the older group, patients with a horizontal and neutral growth pattern were on average in the fifth stage of skeletal maturity and those with a vertical growth pattern in the fourth stage. Conclusion: According to the growth pattern, patients differ in the stage of skeletal maturity.
Received: April 26, 2021

Accepted: July 29, 2021

Address for correspondence Matea Stunja

University Hospital Centre Zagreb Department of Orthodontics Gundulićeva 5, 100000 Zagreb matea.stunja@gmail.com
MeSH terms: Cephalometry; Age Determination by Skeleton Author keywords: Vertical Growth Pattern; Horizontal Growth Pattern; Skeletal Maturation

\section{Introduction}

In orthodontics, determining biological age, in addition to knowing the chronological age of patients, is important for the diagnosis and development of a treatment plan (1). For development of a treatment plan it is very important to evaluate if the patient is near the peak of pubertal growth. It is believed that growth modification therapy of the maxilla is more effective when it starts before the peak of pubertal growth, while the approach that modifies mandibular growth should start after the peak (2).

To assess different stages of growth spurt we can use the following two methods: the hand-wrist radiographs and cervical vertebral maturation (CVM) method in the lateral cephalometric radiograph. Wong et al. have validated the CVM method and they made conclusion that since cephalometric radiograph is routinely made before entering any orthodontic treatment, to prevent unnecessary radiation for additional Xrays of hand, nowadays, this method is used as a gold standard

\section{Uvod}

Određivanje biološke dobi, uz poznavanje kronološke dobi pacijenata, važno je za postavljanje ispravne ortodontske dijagnoze i pripremu plana terapije (1). Za dobar plan terapije veoma je važno znati je li pacijent blizu vrhunca pubertetskog rasta. Poznato je da s terapijom modifikacije rasta u maksili valja početi prije vrhunca pubertetskog rasta, a terapija u mandibuli uspješnija je ako se provodi nakon vrhunca (2).

$\mathrm{Za}$ određivanje različitih stadija pubertetskog rasta možemo se koristiti dvjema metodama - RTG snimkom kostiju šake i zgloba te stupanjem zrelosti cervikalne kralježnice (CVM). Wong i suradnici analizirali su CVM metodu i zaključili da, zbog rutinske primjene kefalograma prije početka ortodontske terapije, a radi sprječavanja nepotrebnog zračenja tijekom snimanja dodatne RTG snimke, danas je CVM metoda zlatni standard u određivanju stupnja pubertetskog rasta (3). 
in determining pubertal growth (3). In terms of timing the right treatment and getting a better result, the knowledge of the skeletal maturation in association with craniofacial growth is also very important (4). The chronological and biological age of the patient, combined with knowledge of the type of craniofacial growth allows us to predict the right timing and outcome of orthodontic therapy; therefore, they are crucial in clinical as well as in scientific work. In the available literature there are studies which compared dental age with skeletal maturity $(5,6)$, but the relationship between skeletal maturation and growth pattern has not yet been clarified; therefore, the aim of this cross-sectional retrospective study was to assess whether there are differences in skeletal maturation among patients with different vertical facial growth patterns.

\section{Material and methods}

The sample included 146 pretreatment lateral cephalographs (82 females and 64 males) of patients aged 12-18 selected from the Department of Orthodontics, University Hospital Centre Zagreb. Lateral cephalographs were routinely made before orthodontic treatment. More than a thousand patient files were reviewed. The study was approved by the Ethics Committee of the School of Dental Medicine, University of Zagreb since the cephalographs were made according to diagnostic procedures. The patient's parents signed a voluntary written informed consent. All subjects with determined craniofacial anomalies, skeletal deviations in the sagittal dimension, respiratory problems, and positive history of unfavorable habits were excluded from the study because of the possible effect on the development of the alveolar bone and dimensions of the midface.

\section{Rtg cephalometric analysis}

To assess the growth pattern, a cephalometric analysis was performed using the Dolphin 10.5 software. All variables that were used for this purpose are shown in Table 1. The norms of all values were derived from a previous study on subjects with normal occlusion from the Croatian ethnicity (7).

\section{Assessment of cervical vertebral maturation index}

Cervical vertebral maturation was determined on lateral cephalometric radiographs using cervical vertebrae maturation stages (CVMS) (8-11), a method modified by Baccetti et al. (12). The morphology of the bodies of the second $(\mathrm{C} 2)$, third (C3), and fourth (C4) cervical vertebrae were an-
Osim poznavanja stupnja pubertetskoga rasta, važno je znati i odnos stupnja pubertetskoga rasta $s$ kraniofacijalnim rastom (4). Kronološka i biološka dob pacijenata, uz poznavanje vrste kraniofacijalnog rasta, utječe na pravodobni početak i predvidanje rezultata ortodontske terapije i zato su vrlo važne kako u znanstvenom tako i u kliničkom radu. U literaturi se mogu pronaći studije u kojima se uspoređuju dentalna dob pacijenata i njihova skeletna zrelost $(5,6)$, ali odnos obrasca kraniofacijalnog rasta i skeletne zrelosti još nije potpuno razjašnjen. U skladu s tim, svrha ovoga retrospektivnog istraživanja bila je odrediti postoje li razlike u stupnju skeletne zrelosti kod pacijenata s različitim obrascima rasta kraniofacijalnog sustava.

\section{Materijali i metode}

$\mathrm{U}$ istraživanje je bilo uključeno 146 lateralnih rendgenskih kefalograma pacijenta (82 od žena i 64 od muškaraca) u dobi od 12 do 18 godina izabranih u Zavodu za ortodonciju Kliničkoga bolničkoga centra Zagreb. Lateralni kefalogrami snimani su rutinski neposredno prije početka ortodontske terapije, a ukupno je pregledano više od 1000 pacijenata. Istraživanje je odobrilo Etničko povjerenstvo Stomatološkog fakulteta Sveučilišta u Zagrebu. Roditelji pacijenata potpisali su informirani pristanak za sudjelovanje u istraživanju. Svi pacijenti s kraniofacijalnim anomalijama, skeletnim devijacijama u sagitalnoj dimenziji, respiratornim problemima te neodgovarajućim navikama nisu bili uključeni u istraživanje zbog mogućeg utjecaja na razvoj alveolarne kosti i lica.

\section{Rendgenska kefalometrijska analiza}

$\mathrm{Za}$ određivanje obrasca rasta lica korištena je kefalometrijska analiza u programu Dolphin 10.5.

Sve korišstene varijable nalaze se u tablici 1 . Srednje vrijednosti dobivene su iz dosadašnjih istraživanja provedenih na pacijentima s normalnom okluzijom iz hrvatske populacije (7).

\section{Određivanje stupnja zrelosti cervikalnih kralježaka}

Stupanj zrelosti cervikalnih kralježaka određen je kefalogramom, koristeći se CVM metodom $(8-11)$ prema Baccettiju i suradnicima (12). Analizirana je morfologija tijela drugoga (C2), trećega (C3) i četvrtoga (C4) cervikalnog kralješka. Sve analize i mjerenja obavio je jedan istraživač. Ra-

Table 1 Cephalometric variables used in this study

Tablica 1. Kefalometrijske varijable korištene u istraživanju

\begin{tabular}{c|l|c|c|c} 
No. & \multicolumn{1}{|c|}{$\begin{array}{c}\text { Measured values } \bullet \\
\text { Mjerene vrijednosti }\end{array}$} & $\begin{array}{c}\text { Name of the measure } \bullet \\
\text { Naziv mjere }\end{array}$ & $\begin{array}{c}\text { Mean value } \bullet \text { Srednja } \\
\text { vrijednost }\end{array}$ & $\begin{array}{c}\text { Type of measurement } \bullet \\
\text { Vrsta mjere }\end{array}$ \\
\hline 1. & Y axis $\bullet$ Kut Y osi & N-S - Gn & $66.5 \pm 3.5$ & Angular $\bullet$ Angularna \\
\hline 2. & Basal plane angle $\bullet$ Medučeljusni kut & sp - pm: go- $\mathrm{m}$ & $25 \pm 5$ & Angular $\bullet$ Angularna \\
\hline 3. & Articular angle $\bullet$ Zglobni kut & $\mathrm{S}-\mathrm{Ar}-\mathrm{Go}$ & $39.5 \pm 5$ & Angular $\bullet$ Angularna \\
\hline 4. & Gonial angle $\bullet$ Mandibularni kut & $\mathrm{M}-\mathrm{Go}-\mathrm{Ar}$ & $127.5 \pm 5$ & Angular $\bullet$ Angularna \\
\hline 6. & Upper gonial angle $\bullet$ Gornji odsječak mandibularnog kuta & $\mathrm{N}-\mathrm{Go}-\mathrm{Ar}$ & $54.5 \pm 4$ & Angular $\bullet$ Angularna \\
\hline 7. & Mandibular plane angle $\bullet$ Kut nagiba baze mandibule & $\mathrm{N}-\mathrm{S}: \mathrm{Go}-\mathrm{M}$ & $32.4 \pm 4.7$ & Angular $\bullet$ Angularna \\
\hline 8. & $\begin{array}{l}\text { Anterior and posterior face height ratio } \bullet \\
\text { Prednji i stražnji omjer duljine lica }\end{array}$ & S-Go: N-Me & $61 \pm 2 \%$ & \\
\hline
\end{tabular}


alyzed. All analysis and measurement were performed by one researcher. To assess the reproducibility, 30 randomly selected lateral cephalographs were reevaluated eight weeks later by the same investigator. The results were evaluated by the Spearman-Brown formula.

\section{Statistical analysis}

Statistical calculations were made by using Statistical Package for Social Sciences software for Windows software system (version PASW 18), (SPSS Inc., Chicago, SAD). The level of significance was set at p-values of $<.05$. To test the normality of distribution, the Kolmogorov-Smirnov and Shapiro-Wilk tests were used. Each variable was presented by the mean, standard deviation and maximum and minimum values. For the numerical variables (degree of bone maturity, age), the following parametric tests were used: T-test, ANOVA and associated post hoc Scheffe test.

\section{Results}

\section{Patients' characteristics}

The study involved 146 patients aged 12 - 18 years (average age 14.9 years). According to gender, there were 64 male patients (43.83\%) and 82 female patients (56.17\%). The distribution of patients by gender did not differ according to age (T-test, $\mathrm{p}=0.315$ ).

According to growth pattern, the subjects were allocated into three groups. In Group 1, there were 48 subjects with horizontal growth pattern, in Group 2, there were 48 subjects with vertical growth pattern and in Group 3, there were 50 subjects with neutral growth pattern.

\section{Skeletal maturation and growth patterns}

The mean values for skeletal maturity for subjects with different growth patterns are shown in Table 2 . The obtained difference was statistically significant (ANOVA: $\mathrm{F}=9.417$; d.f. $=2 ;$ p \& lt; 0.001), and the Scheffe test confirms that there was a significant difference between patients with horizontal and vertical growth patterns in the younger group di smanjenja pogreške, nakon osam tjedana ponovno je analizirano 30 nasumično izabranih lateralnih kefalograma. Za obradu rezultata korišstena je Spearman-Brownova formula.

\section{Statistička analiza}

Statistička analiza obavljena je u programu Statistical Package for Social Sciences na Windowsovu operacijskom sustavu (version PASW 18), (SPSS Inc., Chicago, SAD). Stupanj značajnosti iznosio je $\mathrm{p}<, 05$. Stupanj distribucije određen je $s$ pomoću Kolmogorov-Smirnovljeva i Shapiro-Wilkova testa. Svaka varijabla opisana je srednjom vrijednošću, standardnom devijacijom te maksimalnom i minimalnom vrijednošću. Za numeričke varijable (stupanj skeletne maturacije) korišteni su T-test, ANOVA i post hoc Schefferov test.

\section{Rezultati}

\section{Obilježja pacijenata}

U istraživanju je sudjelovalo 146 pacijenata u dobi od 12 do 18 godina (srednja vrijednost 14,9 godina). Prema spolu su 64 (43,83 \%) pacijenta bili muškarci, a $82(56,17 \%)$ žene. Distribucija prema spolu nije se razlikovala unutar dobnih skupina (T-test, $\mathrm{p}=0,315$ ).

Prema obrascu rasta pacijenti su podijeljeni u tri skupine. U 1. grupi bilo je 48 pacijenata s horizontalnim obrascem rasta, u 2. grupu uvršteno je 48 pacijenta $s$ vertikalnim obrascem, a 3. grupa sastojala se od 50 pacijenta s neutralnim obrascem rasta.

\section{Stupanj zrelosti i obrazac rasta}

Srednja vrijednost stupnja skeletnoga sazrijevanja pacijenata $s$ različitim obrascem rasta prikazana je u tablici 2. Dobiveni rezultati statistički su značajni (ANOVA : F = 9,417; d. f. = 2; p i lt; 0,001), a pokazuju sljedeće: Schefferov test potvrđuje statistički značajne razlike između pacijenata s horizontalnim i vertikalnim obrascem rasta unutar mlađe dobne skupi-

\begin{tabular}{|c|c|c|c|c|c|}
\hline \multirow[b]{2}{*}{ Growth pattern $\cdot$ Obrazac rasta } & \multicolumn{5}{|c|}{ CVMS } \\
\hline & $\mathbf{N}$ & $\begin{array}{c}\text { Mean value }(\mathrm{M}) \bullet \text { Srednja } \\
\text { vrijednost }(\mathrm{M})\end{array}$ & SD & f-ratio & $\mathbf{p}$ \\
\hline Horizontal $\bullet$ Horizontalni & 48 & 4.0 & 0.97 & \multirow{3}{*}{9.417} & \multirow{3}{*}{0.000} \\
\hline Vertical $\bullet$ Vertikalni & 48 & 3.4 & 1.00 & & \\
\hline Neutral • Neutralni & 50 & 4.1 & 0.95 & & \\
\hline Total • Ukupno & 146 & 3.9 & 1.03 & & \\
\hline
\end{tabular}

Table 3 Analysis of variance of growth patterns and stage of skeletal maturity

Tablica 3. Analiza varijance obrasca rasta i stupnja skeletne zrelosti

\begin{tabular}{l|l|c|c}
\multicolumn{1}{c|}{$(\mathbf{I})$} & \multicolumn{1}{|c}{$(\mathbf{J})$} & \multicolumn{1}{c}{ (I-J) } & \multicolumn{1}{c}{ p } \\
\multirow{3}{*}{ Horizontal $\bullet$ Horizontalni } & vertical $\bullet$ vertikalni & $.688^{*}$ & $.003^{*}$ \\
\cline { 2 - 4 } Vertical $\bullet$ Vertikalni & neutral $\bullet$ neutralni & -.098 & .882 \\
\hline \multirow{2}{*}{ horizontal $\bullet$ horizontalni } & $-.688^{*}$ & $.003^{*}$ \\
\cline { 2 - 4 } & neutral $\bullet$ neutralni & $-.786^{*}$ & $.001^{*}$
\end{tabular}


and between neutral and vertical growth patterns in the older group of patients ( $\mathrm{p} \& \mathrm{lt}$; 0.05), while there was no significant difference in the degree of skeletal maturation between horizontal and neutral growth pattern (p \& gt; 0.05) (Table 3).

Relationship between skeletal maturation and growth pattern in different age groups

Patients were divided into two age groups. $57.5 \%$ of them were in the first group (12 to 15 years) and $42.5 \%$ in the second group (16 to 18 years).

According to growth patterns and degree of skeletal maturity development, the distribution of the first group is shown in Figure 1 and of the second group in Figure 2.

In the age group 12-15 years, the obtain results revealed a statistically significant difference in stage of skeletal development between the subjects with horizontal and vertical growth patterns, (ANOVA; $\mathrm{F}=4.802 ; \mathrm{P}=0.011$ ) (Table 4).

In the age group 16-18 years, statistically significant differences were found between patients with horizontal and vertical growth patterns and those with vertical and neutral growth patterns, (ANOVA; $\mathrm{F}=4.802 ; \mathrm{P}=0.011$ ) (Table 5). ne te između onih $s$ neutralnim i vertikalnim rastom $u$ starijoj dobnoj skupini (p i lt; 0,05). Kod pacijenata s horizontalnim i neutralnim obrascem rasta nije pronađena statistički značajna razlika u stupnju skeletne zrelosti (p i gt; 0,05) (tablica 3.).

Odnos skeletne zrelosti i obrasca rasta unutar različitih skupina

Pacijenti su podijeljeni u dvije skupine. Njih 57,5\% nalazi se u prvoj skupini (12 - 15 godina), a 42,5 \% svrstano je u drugu dobnu skupinu (16 - 18 godina).

Na slici 1. je distribuciju pacijenata prve skupine prema odgovarajućem obrascu rasta i stupnju skeletne zrelosti, a distribucija pacijenata druge skupine nalazi se na slici 2.

Unutar dobne skupine od 12 do 15 godina rezultati pokazuju statistički značajnu razliku u stupnju skeletne zrelosti između pacijenata s horizontalnim i vertikalnim obrascem rasta (ANOVA; $\mathrm{F}=4,802 ; \mathrm{P}=0,011$ ) (tablica 4.).

Unutar starije dobne skupine (16 - 18 godina) statistički značajna razlika pronađena je između pacijenata s horizontalnim i vertikalnim obrascem rasta te $s$ vertikalnim i neutral$\operatorname{nim}($ ANOVA; $\mathrm{F}=4,802 ; \mathrm{P}=0,011$ ) (tablica 5.).

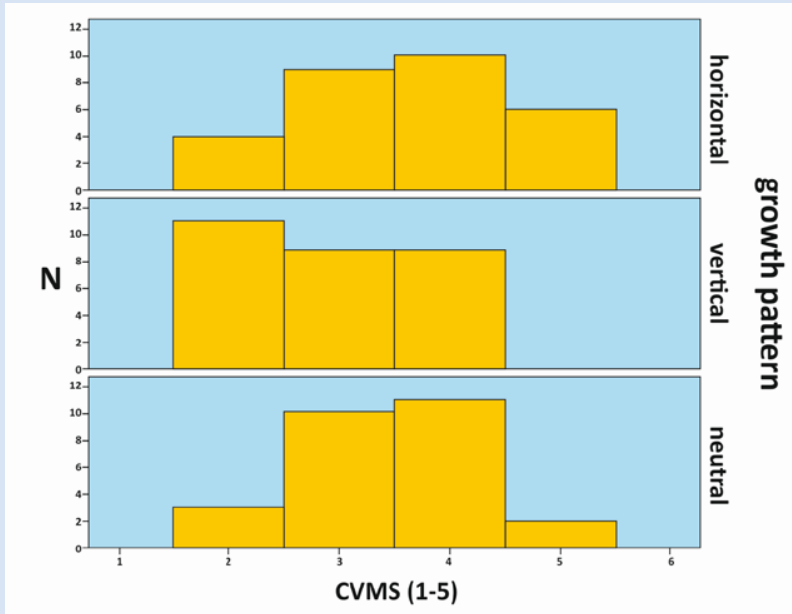

Figure 1 CVMS for different growth pattern in group 12-15 yrs Slika 1. CVMS za različite obrasce rasta u skupini od 12 do 15 godina

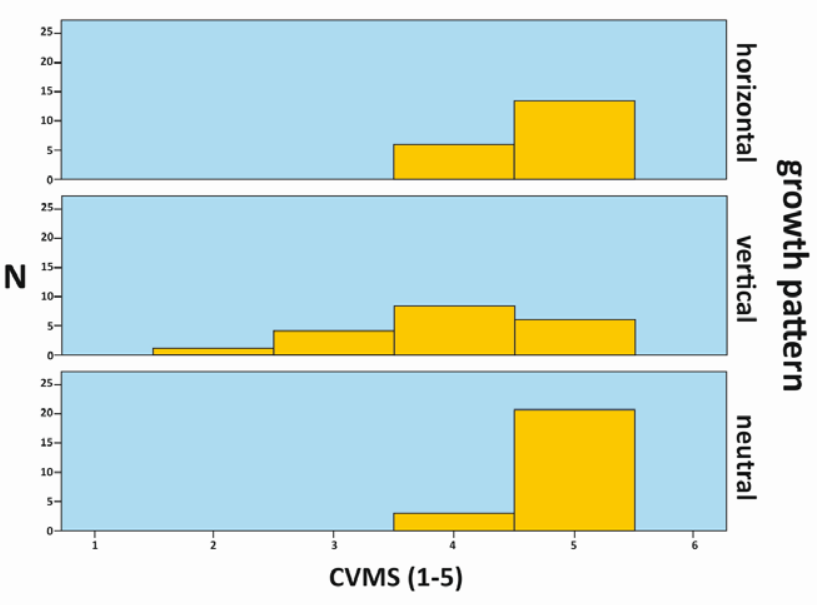

Figure 2 CVMS for different growth pattern in group 16-18 yrs

Slika 2. CVMS za različite obrasce rasta u skupini od 16 do 18 godina

Table 4 CVMS for different growth pattern in group 12-15 yrs, Scheffe post-hoc test

Tablica 4. CVMS za različite obrasce rasta u skupini od 12 do 15 godina, Scheffeov post-hoc test

\begin{tabular}{l|c|c|c} 
& Neutral $\bullet$ Neutralni & Horizontal $\bullet$ Horizontalni & Vertical $\bullet$ Vertikalni \\
\hline Neutral $\bullet$ Neutralni & & .801 & .091 \\
\hline Horizontal $\bullet$ Horizontalni & .801 & & .015 \\
\hline Vertical $\bullet$ Vertikalni & .091 & $\mathbf{. 0 1 5}$ &
\end{tabular}

Scheffe post-hoc test $\bullet$ Scheffeov post-hoc test; $p<0.05$

Table 5 CVMS for different growth pattern in group 16-18 yrs, Scheffe post-hoc test

Tablica 5. CVMS za različite obrasce rasta u skupini od 16 do 18 godina, Scheffeov post-hoc test

\begin{tabular}{l|c|c|c} 
& Neutral $\bullet$ Neutralni & Horizontal $\bullet$ Horizontalni & Vertical $\bullet$ Vertikalni \\
\hline Neutral $\bullet$ Neutralni & & .580 & $\mathbf{. 0 0 0}$ \\
\hline Horizontal $\cdot$ Horizontalni & .580 & & $\mathbf{. 0 0 3}$ \\
\hline Vertical $\bullet$ Vertikalni & $\mathbf{. 0 0 0}$ & $\mathbf{. 0 0 3}$ &
\end{tabular}




\section{Discussion}

The face changes during childhood, adolescence and adulthood. The craniofacial growth is continuous, however, the growth of individual parts of the head does not occur continuously over time (13-16).

The knowledge of the growth pattern and the degree of skeletal maturity in patients is mandatory for the right orthodontic treatment, both timing and type.

The most frequent method to assess skeletal growth is to analyze the cervical vertebrae on routinely made cephalographs, known as the CVMS method (17-20). Szemraj et al. (21) have confirmed that this diagnostic approach has a high degree of correlation with the hand wrist method and it is considered reliable in clinical, as well as in scientific work. Accordingly, in this research, the CVMS method was used to determine skeletal growth.

The obtained results showed a statistically significant difference in skeletal maturation time between patients with vertical and horizontal growth patterns, thus confirming the null hypothesis. Subjects with horizontal and neutral growth patterns aged 12-15 years were on average in the fourth stage of skeletal maturity, while those with a vertical growth pattern were in the third stage of skeletal maturation. Patients in the age group 16-18 years with vertical growth pattern had mean skeletal age in the fourth stage and those with horizontal and neutral growth pattern in the fifth stage.

Gottimukkala et al. (22) have undertaken a comparison of the skeletal age between long and short face children in the South Indian Population and concluded that subjects with vertical growth patterns should be expected to reach higher levels of skeletal maturity than horizontal growers. A possible explanation for the opposite values, from the ones in this study, was a difference in methodology since they have used both hand-wrist radiographs and lateral cephalographs.

Perinetti et al. performed a study on the Italian population. Their results have shown that there is a very small correlation between different craniofacial growth and skeletal maturation, apart from patients with vertical craniofacial growth pattern in CVM stage 3. Those results are statistically significant, but clinically, they can be found only in extreme cases (4). In their research, they have used different cephalometric measurements than ones used in this study. Moreover, there is evidence that besides the growth pattern, some other factors could also influence the level of skeletal maturity, such as genetics, nutrition, socioeconomic status and ethnicity (23). Hence, those are the factors that can explain the differences in results between this and their study.

Due to a lack of similar research the obtained results are very difficult to compare. Furthermore, research should be supplemented by a larger number of growth indicators.

\section{Conclusions}

A difference in the degree of skeletal maturity among subjects with different vertical facial growth patterns was found ( $\mathrm{p}<0.001)$. Patients with horizontal and neutral growth patterns didn't show significant differences in skeletal maturity. Subjects with a vertical growth pattern were in a high-

\section{Rasprava}

Lice se mijenja tijekom djetinjstva, adolescencije i zrele dobi. Kraniofacijalni rast je kontinuiran, no rast pojedinih dijelova glave to ne prati u cijelosti $(13-16)$. Poznavanje obrasca rasta i stupnja skeletne zrelosti prijeko je potrebno za pravodobni početak i odabir ortodontske terapije. Najčešće korištena metoda za određivanje stupnja skeletne zrelosti jest CVM metoda koja se provodi na rutinski snimljenim kefalogramima $(17-20)$. Szemraj i suradnici (21) potvrdili su da navedena metoda ima visok stupanj korelacije s metodom šake i zgloba te je jednako pouzdana u kliničkom i znanstvenom radu. Zbog navedenoga je u ovom istraživanju za odredivanje stupnja skeletne zrelosti korištena ta metoda.

Dobiveni rezultati pokazuju statistički značajnu razliku u stupnju skeletne zrelosti između pacijenata $s$ vertikalnim i horizontalnim obrascem rasta pa je prihvaćena nulta hipoteza. Pacijenti $s$ horizontalnim i neutralnim obrascem rasta u dobi od 12 do 15 godina prosječno su se nalazili u četvrtom stupnju skeletne zrelosti, a oni s vertikalnim pripadali su trećem stupnju. Pacijenti u dobnoj skupini od 16 do 18 godina, $s$ vertikalnim obrascem rasta, prosječno su pripadali četvrtom stupnju skeletne zrelosti, a oni s horizontalnim i neutralnim obrascem najčešće su bili u petom. Gottimukkala i suradnici (22) uspoređivali su među južnom indijskom populacijom stupanj skeletne zrelosti kod djece $s$ dugim i kratkim licem. Prema njihovim rezultatima, kod pacijenata s vertikalnim obrascem rasta očekuje se ranije skeletno sazrijevanje u usporedbi s onima s horizontalnim. Moguće objašnjenje za različite rezultate, od onih dobivenih u ovom istraživanju, jest razlika u odabranoj metodologiji zato što je u njihovu istraživanju korišten i CVM i analiza šake.

Perinetti i suradnici radili su istraživanje na talijanskoj populaciji. Njihovi rezultati pokazuju da je korelacija između različitog stupnja skeletne zrelosti te različitog obrasca rasta veoma mala, osim među pacijentima $s$ vertikalnim obrascem rasta i stupnjem skeletne zrelosti CVM 3. Navedeni rezultati klinički su značajni, ali mogu se primijeniti samo u ekstremnim slučajevima (4). U svojem su se radu koristili drukčijim kefalometrijskim mjerama od onih u ovoj studiji. Nadalje, u literaturi se ističe da, osim obrasca rasta, i drugi čimbenici mogu utjecati na stupanj skeletne zrelosti - genetika, prehrana, socijalno-ekonomski status i etnička pripadnost (23).

Zbog različitih metoda procjene stupnja skeletne maturacije teško je usporediti dobivene rezultate, a ubuduće je potrebno proširiti istraživanje te uzeti u obzir više različitih čimbenika rasta.

\section{Zaključak}

Pronađena je razlika u stupnju skeletne zrelosti među pacijentima $s$ različitim obrascem rasta $(\mathrm{p}<0,001)$. Pacijenti $s$ horizontalnim i neutralnim obrascem nisu pokazali statistički značajnu razliku u stupnju skeletne zrelosti. Pacijenti $s$ vertikalnim obrascem rasta, u usporedbi s onima s horizontalnim 
er stage of skeletal maturity when compared to those with a horizontal and neutral growth pattern for the same chronological age.

\section{Conflict of interest}

The authors report no conflict of interest.

Authors' contributions: A.P. - participated in designing the research as part of a doctoral dissertation, performed all measurements; M.S. - wrote this article; M.Š.A. - participated in the statistical analysis and interpretation of results; S.A.M. - participated in the experimental design; S.M. - mentor, advisor at all phases of conducting the research and writing the article. i neutralnim, a unutar iste dobne skupine, pripadali su višem stupnju skeletne zrelosti.

\section{Sukob interesa}

Autori ističu da nisu bili u sukobu interesa.

Doprinos autora: A. P. - osmislio istraživanje kao dio doktorske disertacije, proveo sve eksperimentalne faze istraživanja; $\mathbf{M}$. S. - napisala članak; M. Š. A. - sudjelovala u statističkoj anlaizi i interpretaciji rezultata; S. A. M. - sudjelovala u eksperimentalnom dizajnu; S. M. - mentor, savjetnik u svim fazama provedbe eksperimenta i pisanja rada.

\section{Sažetak}

Svrha rada: Odrediti postoji li razlika u stupnju skeletne zrelosti između pacijenata s horizontalnim, vertikalnim i neutralnim obrascem vertikalnoga rasta lica. Materijal i metoda: $U$ istraživanju je korišteno 48 laterolateralnih kraniograma pacijenata u dobi od 12 do 18 godina s horizontalnim obrascem vertikalnoga rasta lica, $48 \mathrm{~s}$ vertikalnim i $50 \mathrm{~s}$ neutralnim. Za procjenu obrasca korišteno je osam varijabli iz MOD analize Zagreb 82, a za određivanje stupnja skeletne maturacije metoda prema Baccettiju i Accordu. Rezultati: Statistička analiza pokazala je značajne razlike u stupnju skeletne zrelosti $(p<0,001)$ između pacijenata s horizontalnim i vertikalnim obrascem rasta te između onih $s$ neutralnim i vertikalnim $(p<0,05)$. Između pacijenata s horizontalnim i neutralnim rastom nije bilo statistički značajne razlike. Unutar mlađe dobne skupine (12-15 godina) ustanovljena je statistički značajna razlika $(\mathrm{p}<0,05)$ između pacijenata s horizontalnim i vertikalnim obrascem rasta. U starijoj skupini $(16-18$ godina) pronađena je statistički značajna razlika $(p>0,05)$ u stupnju skeletne zrelosti kod pacijenata s vertikalnim obrascem rasta u odnosu prema onima s horizontalnim i neutralnim. Pacijenti s horizontalnim i neutralnim obrascem rasta unutar mlađe dobne skupine bili su najčešće u četvrtom stupnju skeletne zrelosti, a oni s vertikalnim u trećem. Unutar starije dobne skupine, pacijenti s horizontalnim i neutralnim obrascem rasta najčešće su bili u petom stupnju, a oni s vertikalnim u četvrtom stupnju skeletne zrelosti. Zaključak: S obzirom na obrazac rasta, pacijenti se razlikuju u stupnju skeletne zrelosti.
Zaprimljen: 26. travnja 2021 Prihvaćen: 29. srpnja 2021.

Adresa za dopisivanje Matea Stunja, doktorand Sveučilište u Zagrebu Stomatološki fakultet Gundulićeva 5, 10000 Zagreb matea.stunja@gmail.com

MeSH pojmovi: kefalometrija; određivanje dobi s pomoću kostura Ključne riječi: vertikalni obrazac rasta, horizontalni obrazac rasta, skeletna zrelost

\section{References}

1. Proffit WR, Fields HW Jr, Sarver DM. Ortodoncija. Jastrebarsko: Naklada Slap; 2010.

2. Soegiharto BM, Moles DR, Cunningham SJ. Discriminatory ability of the skeletal maturation index and the cervical vertebrae maturation index in detecting peak pubertal growth in Indonesian and white subjects with receiver operating characteristics analysis. Am J Orthod Dentofacial Orthop. 2008 Aug;134(2):227-37.

3. Wong RW, Alkhal HA, Rabie AB. Use of cervical vertebral maturation to determine skeletal age. Am J Orthod Dentofacial Orthop. 2009;136(4):484.e1-485.

4. Perinetti G, Rosso L, Riatti R, Contardo L. Sagittal and Vertical Craniofacial Growth Pattern and Timing of Circumpubertal Skeletal Maturation: A Multiple Regression Study. Biomed Res Int. 2016;2016:1728712.

5. Srkoč $T$, Meštrović $S$, Anić-Milošević $S$, Šlaj M. Association between dental and skeletal maturation stages in Croatian subjects. Acta Clin Croat. 2015 Dec;54(4):445-52.

6. Felemban NH. Correlation between Cervical Vertebral Maturation Stages and Dental Maturation in a Saudi Sample. Acta Stomatol Croat. 2017 Dec;51(4):283-289.

7. Muretić Z. Computer modification of radiographic cephalometric analysis „Zagreb 82“. Period Biol. 1993;95:137-40.

8. Hassel B, Farman AG. Skeletal maturation evaluation using cervical vertebrae. Am J Orthod Dentofacial Orthop. 1995 Jan;107(1):58-66.

9. Agresti A. Categorical Dana Analysis. 2. ed. New York: John Wiley and sons, Inc.; 2002.

10. Dawson B, Trapp RG. Basic\&Clinical Biostatistics. 3 ed. New York: The McGrawHill Companies, Inc.; 2000.

11. Yavuz I, Ikbal A, Baydaş B, Ceylan I. Longitudinal posteroanterior changes in transverse and vertical craniofacial structures between 10 and 14 years of age. Angle Orthod. 2004 Oct;74(5):624-

12. Baccetti T, Franchi L, McNamara JA Jr. An improved version of the cervical vertebral maturation (CVM) method for the assessment of mandibular growth. Angle Orthod. 2002 Aug;72(4):316-23.
13. Björk A. Variations in the growth pattern of the human mandible: longitudinal radiographic study by the implant method. J Dent Res. 1963;42(1):400-11.

14. Meredith HV. A longitudinal study of growth in face depth during childhood. Am I Phys Anthropol. 1959;17(2):125-35.

15. Meredith HV. Changes in form of the head and face during childhood. Growth. 1960:24:215-64.

16. Lundstrom F, Leighton BC, Richardson A, Lundstrom A. A proportional analysis of some facial height and depth variables in 10 to 16 year old children. Eur J Orthod. 1998 Feb;20(1):35-44.

17. Felemban NH. Correlation between Cervical Vertebral Maturation Stages and Dental Maturation in a Saudi Sample. Acta Stomatol Croat. 2017 Dec;51(4):283-289.

18. O'Reilly M, Yanniello GJ. Mandibular growth changes and maturation of cervical vertebrae - a longitudinal cephalometric study. Angle Orthod. 1988;58(2):179-84.

19. Franchi L, Baccetti T, McNamara JA Jr. Mandibular growth as related to cervical vertebral maturation and body height. Am J Orthod Dentofacial Orthop. 2000 Sep;118(3):335-40.

20. Grave K, Townsend G. Cervical vertebral maturation as a predictor of the adolescent growth spurt. Aust Orthod J. 2003 Apr;19(1):2532.

21. Szemraj A, Wojtaszek-Słomińska A, Racka-Pilszak B. Is the cervical vertebral maturation (CVM) method effective enough to replace the hand-wrist maturation (HWM) method in determining skeletal maturation?-A systematic review. Eur J Radiol. 2018 May;102:125-128.

22. Gottimukkala P, Gandikota CS, Challa PL. Assessment of skeletal and dental maturation of short and long-face children of South Indian population. J Ind Orthod Soc. 2012; 46(3):148-53.

23. Anne-Simone Parent, Grete Teilmann, Anders Juul, Niels E Skakkebaek, Jorma Toppari, Jean-Pierre Bourguignon. The timing of normal puberty and the age limits of sexual precocity: variations around the world, secular trends, and changes after migration. Endocr Rev. 2003 Oct;24(5):668-93. 